\begin{tabular}{cc}
\hline International Journal of Engineering \& Technology, $7(2.20)(2018) 321-325$ \\
SPC & Website: www.sciencepubco.com/index.php/IJET \\
Research paper & International Journal of Engineering \& Technology \\
\hline
\end{tabular}

\title{
A Comparative Study of Flat Slabs Using Different Shear Reinforcement Parameters
}

\author{
N. Girish ${ }^{1}$, N. Lingeshwaran ${ }^{2}$ \\ ${ }^{I}$ M.Tech student, Koneru Lakshmaiah Education Foundation, Guntur, Andhra Pradesh, India. \\ ${ }^{2}$ Assistant Professor, Koneru Lakshmaiah Education Foundation, Guntur, Andhra Pradesh, India. \\ *Corresponding author E-mail:girish.narra@gmail.com
}

\begin{abstract}
Punching shear failure is a brittle failure and it is one of the most important types of failure to be considered while designing a reinforced concrete flat slab. This paper aims to study the performance of reinforced concrete flat slabs equipped with different punching shear reinforcement parameters. Three flat slab specimens were cast where two specimens contain punching shear reinforcement in the form of shear stirrups and structural shearbands. The test specimens have length and width of $1000 \mathrm{~mm}$ and thickness of $185 \mathrm{~mm}$ for the slabs. The slabs are connected to a column at the center with length and breadth of $300 \mathrm{~mm}$ and a depth of $700 \mathrm{~mm}$. The test specimens were supported by steel plates with length and breadth of $150 \mathrm{~mm}$ and a thickness of $25 \mathrm{~mm}$ at the four corners of the slab. The test specimens are loaded on the column face at the top. The deflection, strain and crack pattern were observed and recorded.
\end{abstract}

Keywords: Flat slab; Punching shear; Shearbands; Shear reinforcement; Shear stirrups.

\section{Introduction}

Usually, in a normal framed structure, the slabs are supported by beams and columns. A slab that rests directly on the columns without the provision of beams is called a flat slab. Unlike conventional slabs, the load applied on the flat slab is transferred directly to the column which is a relatively small area. Construction of a flat slab has its own advantages like good architectural appearances, easier formwork, shorter construction time, reduced building height and better illumination. But in the flat slab system, it is not possible to have larger spans and the thickness of the slab is more when compared to conventional reinforced concrete twoway slab system.

Punching shear failure is one of the main types of failure that occurs in a flat slab. When the load is applied on the slab, large shear forces and bending moments occur near the columns and it leads to failure of the slab by punching around the column. Punching shear failure is a brittle failure. It is caused by shear diagonal cracks that develop through the full slab thickness and forms a frustum pyramid around the column. In other words, the column and slab completely get separated on failure. The load is then transferred to adjacent columns which leads to overloading them and eventually causes a progressive collapse of the whole structure.

There are numerous strategies which can be implemented to prevent the punching shear failure in a flat slab. Some of them are increasing the thickness of the slab, providing drop panels and column heads, reducing the application of loads and providing shear reinforcement. But these methods must be adopted during the design of flat slab. The first four options just add to the cost of construction and thus not recommended. So, we provide shear reinforcement to avoid the punching shear failure.
Introducing punching shear reinforcement to the flat slab ensures the enhancement of its strength and ductility. We can provide punching shear reinforcement in the form of shear stirrups, structural shear studs, structural shearbands, lattice shear reinforcement and UFO punching preventer[1]. This paper studies the behavior of reinforced concrete flat slab when shear stirrups and the structural shear bands are used as shear reinforcement.

\section{Experimental program}

In this present study, an interior panel with length and width of $6 \mathrm{~m}$ supported by columns with length and width of $300 \mathrm{~mm}$ was considered and the analysis of the panel was done manually using direct design method. A live load of $5 \mathrm{kN} / \mathrm{m}^{2}$ was taken and the moments calculated using this method of analysis was used to design the flat slab as per the Indian code, IS 456: 2000[2].

A total of three reinforced concrete slabs were cast and were tested on the loading frame. The main aim of this study was to study the performance and behavior of reinforced concrete flat slabs both with and without the provision of shear reinforcement. The details of the cross-section and reinforcement of the three slab specimens are listed below.

\subsection{Slab Details}

The three slabs were given codes FS (Flat slab) 1 to 3 . FS1 was the control specimen and had no shear reinforcement. FS2 and FS3 were provided with punching shear reinforcement in the form of shear stirrups and structural shearbands respectively. The crosssectional details of the three slab specimens are described in table 1. 
Table 1: Dimensions of flat slab.

\begin{tabular}{ccccccc}
\hline & \multicolumn{3}{c}{ Slab } & \multicolumn{3}{c}{ Column } \\
\cline { 2 - 6 } $\begin{array}{c}\text { Speci- } \\
\text { men }\end{array}$ & $\begin{array}{c}\text { Lengt } \\
\mathrm{h} \\
(\mathrm{mm})\end{array}$ & $\begin{array}{c}\text { Width(m } \\
\mathrm{m})\end{array}$ & $\begin{array}{c}\text { Dept } \\
\mathrm{h} \\
(\mathrm{mm} \\
\text { FS1 }\end{array}$ & $\begin{array}{c}\text { Lengt } \\
\mathrm{h}\end{array}$ & $\begin{array}{c}\text { Width(m } \\
\mathrm{m})\end{array}$ & $\begin{array}{c}\text { Height } \\
\mathrm{m})\end{array}$ \\
\hline FS2 & 1000 & 1000 & 185 & 300 & 300 & 700 \\
FS3 & & & & & & \\
\hline
\end{tabular}

\subsection{Shear Reinforcement}

Out of the three slab specimens, only two specimens were provided with punching shear reinforcement in the form of shear stirrups and structural shearbands.

For slab FS2, punching shear reinforcement was provided in the form of shear stirrups. Shear stirrup is one of the most commonly used types of shear reinforcement. It can be provided in the form of single or multiple legs, closed or castellated. In this study, single legged stirrups were used to connect the top and bottom reinforcement of the slab-column joint. 8mm diameter bars of Fe500 grade steel is bent into required lengths and are placed around the column connecting the top and bottom horizontal reinforcement at a distance of $45 \mathrm{~mm}$ from the column face.
For slab FS3, structural shearbands were provided as shear reinforcement. The shearbands were made of high ductility and high strength steel strips of width $30 \mathrm{~mm}$ and a thickness of $0.5 \mathrm{~mm}[3]$. The tensile strength of the strip was found to be $1200 \mathrm{~N} / \mathrm{mm}^{2}$. The steel strips were also punched with $8 \mathrm{~mm}$ diameter holes. These holes proved to improve the anchoring characteristics over short lengths. These strips were bent with vertical legs and then anchored to the top mat of the reinforcement around the column at a distance of $45 \mathrm{~mm}$ from the column face.

\subsection{Reinforcement Details}

The longitudinal reinforcement for all three slab specimens was the same. But, for the slabs FS2 and FS3, additional shear reinforcement was provided. The detailing of reinforcement for the slab and column is shown in table 2 and table 3 respectively. Figure 1 shows the reinforcement details of slab FS1, which has no shear reinforcement in it. Figure 2 shows the reinforcement details of slab FS2, which has shear reinforcement in the form of open legged stirrups. Figure 3 shows the reinforcement details of slab FS3, which has shear reinforcement in the form of structural shearbands.

Table 2: Detailing of reinforcement in the slab

\begin{tabular}{|c|c|c|c|c|c|c|}
\hline \multirow{2}{*}{ Specimen } & \multicolumn{3}{|c|}{ Longitudinal Reinforcement } & \multicolumn{3}{|c|}{ Shear Reinforcement } \\
\hline & No \& Dia & $\mathrm{A}_{\mathrm{st}}\left(\mathrm{mm}^{2}\right)$ & $\mathrm{p}_{\mathrm{t}}(\%)$ & No \& Dimensions & $\mathrm{A}_{\mathrm{st}}\left(\mathrm{mm}^{2}\right)$ & $\mathrm{p}_{\mathrm{t}}(\%)$ \\
\hline FS1 & $\begin{array}{c}\text { 8No-10mm(Top) } \\
\text { 8No-12mm (Bottom) }\end{array}$ & 1533.1 & 0.82 & & & \\
\hline FS2 & $\begin{array}{c}\text { 8No-10mm(Top) } \\
8 \mathrm{No}-12 \mathrm{~mm} \text { (Bottom) }\end{array}$ & 1533.1 & 0.82 & 12No-8mm Dia & 603.19 & 0.32 \\
\hline FS3 & $\begin{array}{c}\text { 8No-10mm(Top) } \\
8 \mathrm{No}-12 \mathrm{~mm} \text { (Bottom) }\end{array}$ & 1533.1 & 0.82 & $\begin{array}{l}\text { 4No-30mm wide, } 0.5 \mathrm{~mm} \\
\text { thick }\end{array}$ & 60 & 0.16 \\
\hline
\end{tabular}

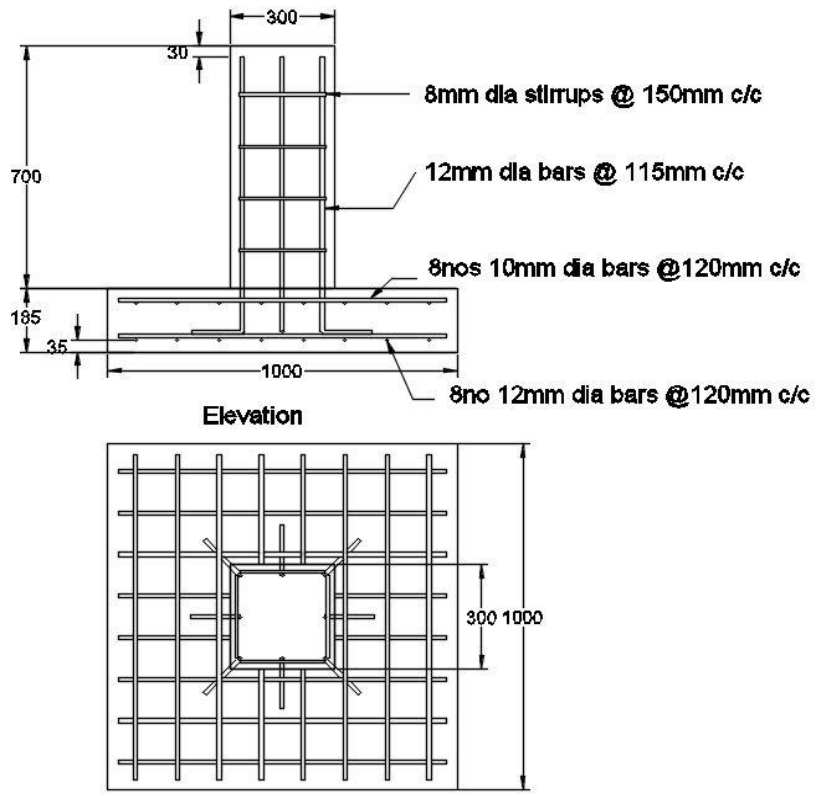

Plan

Figure 1: Reinforcement detailing of slab FS1.
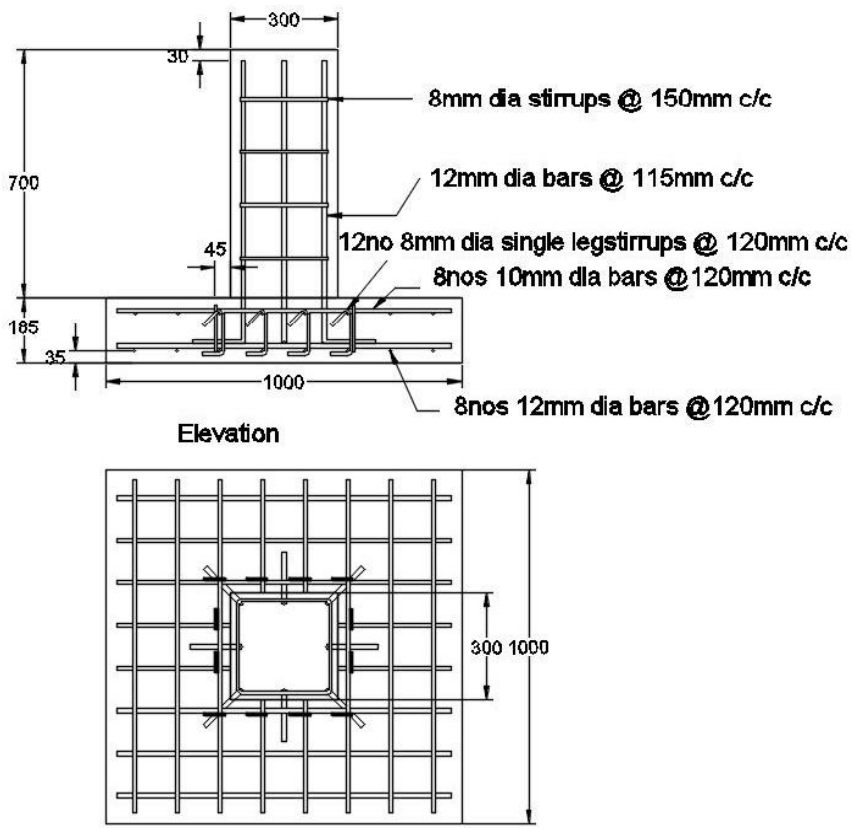

Plan

Figure 2: Reinforcement detailing of slab FS2.

Table 3: Detailing of reinforcement in the column.

\begin{tabular}{cccccc}
\hline \multirow{2}{*}{ Specimen } & \multicolumn{2}{c}{ Longitudinal Reinforcement } & \multicolumn{3}{c}{ Shear Reinforcement } \\
\cline { 2 - 5 } & No \& Dia & $\mathrm{A}_{\text {st }}\left(\mathrm{mm}^{2}\right)$ & $\mathrm{p}_{\mathrm{t}}(\%)$ & No \& Dia & $\mathrm{A}_{\text {st }}\left(\mathrm{mm}^{2}\right)$ \\
\hline FS1 & 8 No-12mm & 904.78 & 0.43 & 4 No-8mm & 201.66 \\
FS2 & 8 No-12mm & 904.78 & 0.43 & 4 No-8mm & 201.66 \\
FS3 & 8 No-12mm & 904.78 & 0.43 & 4 No-8mm & 0.09 \\
\hline
\end{tabular}




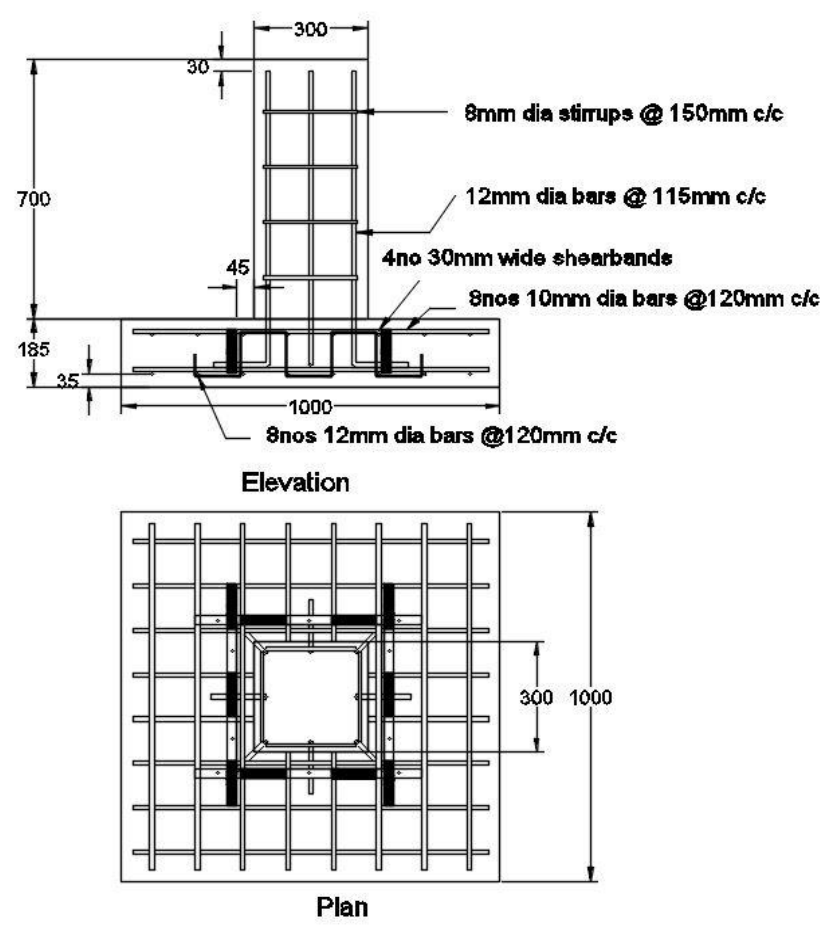

Figure 3: Reinforcement detailing of slab FS3.

\subsection{Concrete}

Concrete used for the three slab specimens was designed according to IS 10262: 2009[4]. Ready-mix concrete of grade M35 with a mix design- 1:2:3.5 was used. In addition, 1\% SP430 admixture was added to the concrete mix to increase its workability. The concrete was compacted by vibrators and after casting, the three slabs were cured for 28 days. Three concrete cubes of size $150 \mathrm{~mm} \times 150 \mathrm{~mm} \times 150 \mathrm{~mm}$ were cast using the same sample and the cubes were tested on the same day as that of the slab specimens. The compressive strength obtained for the concrete mix design is shown in Table 4.

Table 4: Compressive strength of concrete.

\begin{tabular}{cccc}
\hline Specimen & FS1 & FS2 & FS3 \\
\hline Load $(\mathrm{kN})$ & 860 & 900 & 880 \\
Load $(\mathrm{kN})$ & 920 & 860 & 910 \\
Load $(\mathrm{kN})$ & 900 & 910 & 930 \\
Compressive Strength $\left(\mathrm{N} / \mathrm{mm}^{2}\right)$ & 38.95 & 38.81 & 39.53 \\
\hline
\end{tabular}

\subsection{Test Setup}

The three slab specimens were tested on a loading frame of 200 tons capacity in the structural laboratory of K.L Education Foundation. Generally, in real practice, the load is transferred from the slab and then to column. So, in order to test the specimens, the slab must be on top above the column. But for reasons concerning safety and stability, the specimens are inverted and tested. The three slab specimens are supported by steel plates of length and width of $150 \mathrm{~mm}$ and a thickness of $25 \mathrm{~mm}$ on four corners and the load is applied to the column face through hydraulic jack at the top. The load applied on the flat slab specimens was measured using a compression loading cell. LVDT (Linear Variable Differential Transducer) was placed at the bottom of the slab at the center, where the displacement of the member at that point was measured. Two strain gauges were fixed, one to the column face at $300 \mathrm{~mm}$ from the top and the other to the face of the slab at $75 \mathrm{~mm}$ from the top. The test setup is shown in figure 4 .

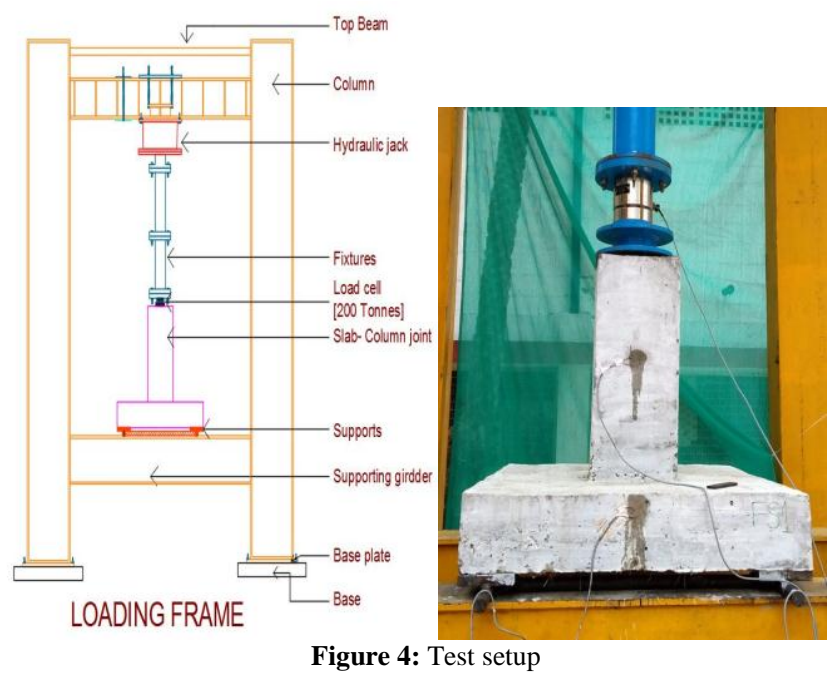

\section{Results and discussions}

\subsection{Crack pattern}

The specimen FS1, which was a control specimen failed suddenly in punching shear. The crack pattern of the specimen is shown in figure 5. A frustum pyramid was also formed on the face of the slab. Cracks were also formed around the column and also at the top and bottom faces of the slab which shows the evidence of punching.

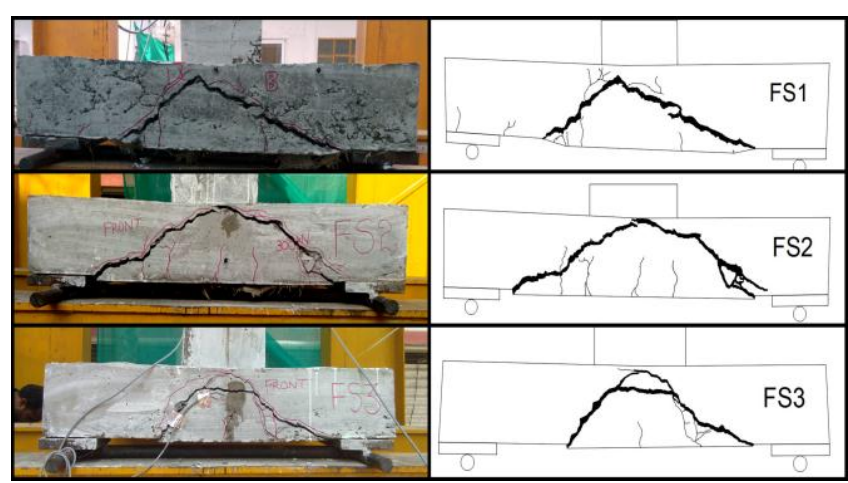

Figure 5: Observed crack pattern of flat slab specimens.

Specimens FS2 and FS3 contained shear reinforcement and their crack pattern were similar to that of slab FS1. But, initial cracks were observed and upon further loading, FS2 and FS3 failed due to punching shear and their failure was ductile in nature. The crack pattern for the specimens FS2 and FS3 is shown in figure 5.

\subsection{Load Vs Deflection}

The specimen FS1 failed at a load of $310 \mathrm{kN}$ with a deflection of $8.19 \mathrm{~mm}$ and the failure was of brittle nature. FS2 had a cracking load of $300 \mathrm{kN}$ and had a maximum load carrying capacity of $445 \mathrm{kN}$ with a deflection of $9.98 \mathrm{~mm}$. FS3 had a cracking load of $206 \mathrm{kN}$ and had a load carrying capacity of $378.5 \mathrm{kN}$ with a deflection of $8.78 \mathrm{~mm}$. The load Vs displacement graph for the three flat slab specimens is shown in Figure 6. 


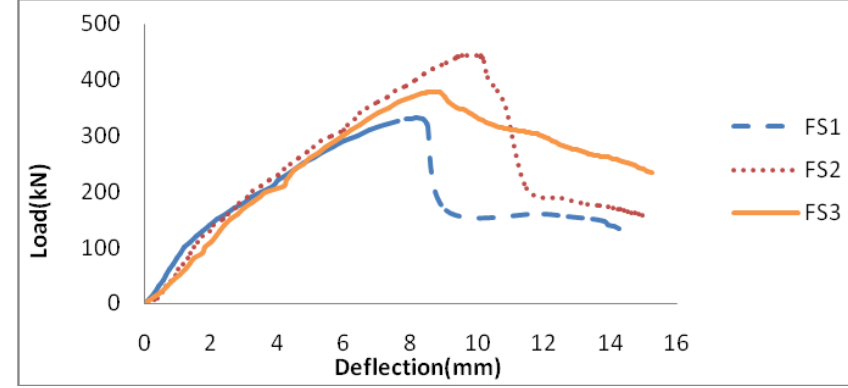

Figure 6: Load Vs displacement graph of flat slab specimens.

\subsection{Stiffness Degradation}

The stiffness of a body is the extent to resist deformation when a load is applied on it. Figure 7 shows the graph plotted between stiffness and deflection of the specimens. In other words, the graph shows the stiffness degradation of the three slab specimens. As the load is applied on the specimens, the stiffness started reducing gradually. But when punching occurred, stiffness in FS1 and FS2 dropped suddenly but more in FS1. In FS3 stiffness continued to reduce gradually until failure.

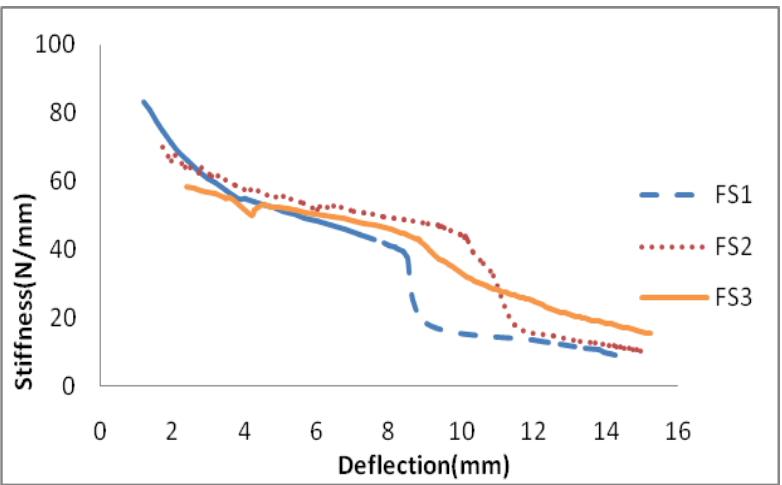

Figure 7: stiffness degradation of flat slab specimens.

\subsection{Stress Vs Strain}

Figure 8 shows the stress- strain relation between the three flat slab specimens. Initially, when the load is applied on the specimens, the stress was directly proportional to strain. But when punching occurred in the slab, there was a sudden drop in stress in FS1 and FS2, gradual drop in FS3 and the elasticity of the specimen ceased to exist. It can be observed that the stress in FS2 is greater than the other two specimens.

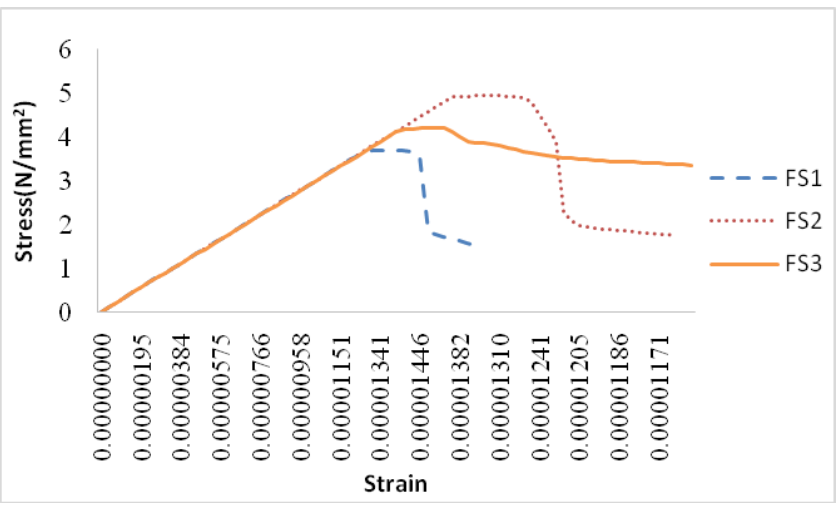

Figure 8: Stress Vs strain graph of flat slab specimens.

\subsection{Load Vs Strain}

The load- strain relation between the three flat slab specimens is shown in figure 9. The strain in the specimens increased proportionally as the load is applied on them. When the maximum load carrying capacity of the specimen is reached, the strain increased rapidly in the specimens even without a further increase in load.
When punching occurred in FS1, the load dropped suddenly but the strain in the specimen remained constant. In FS2, the load dropped but not as severe as FS1, the strain increased in low quantity. In FS3, after punching occurred, there was a major increase in strain even for a small reduction in load.

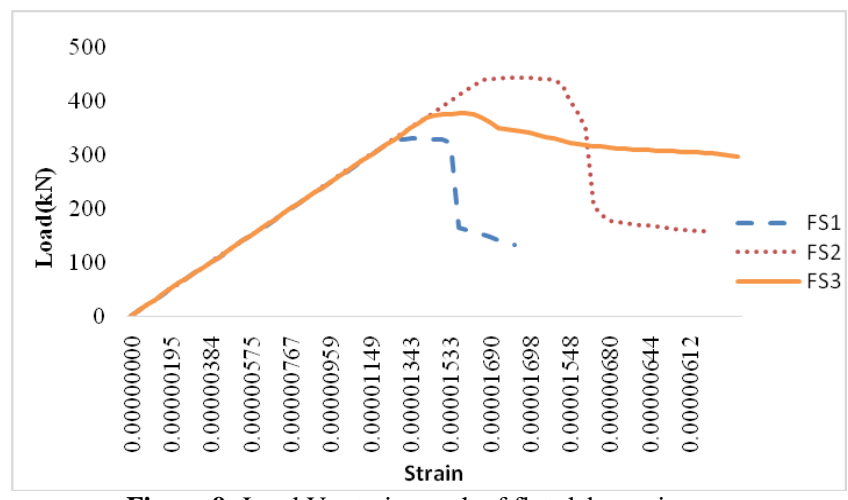

Figure 9: Load Vs strain graph of flat slab specimens.

\subsection{Shear Strength Vs Drift Ratio}

Figure 10 shows a normalized graph between shear strength and drift ratio of all the flat slab specimens. The shear strength of a material is defined as the strength against the type of yield or structural failure where the material or component fails in shear. Drift ratio is defined as the ratio of maximum drift to a total height of the specimen. Initially, during loading, the shear strength of the three specimens increased with increase in drift ratio and the graph was almost linear. When punching occurred, the shear strength of FS1 and FS2 dropped suddenly but gradually decreased in FS3. Shear strength was highest in FS2 and lowest in FS1.

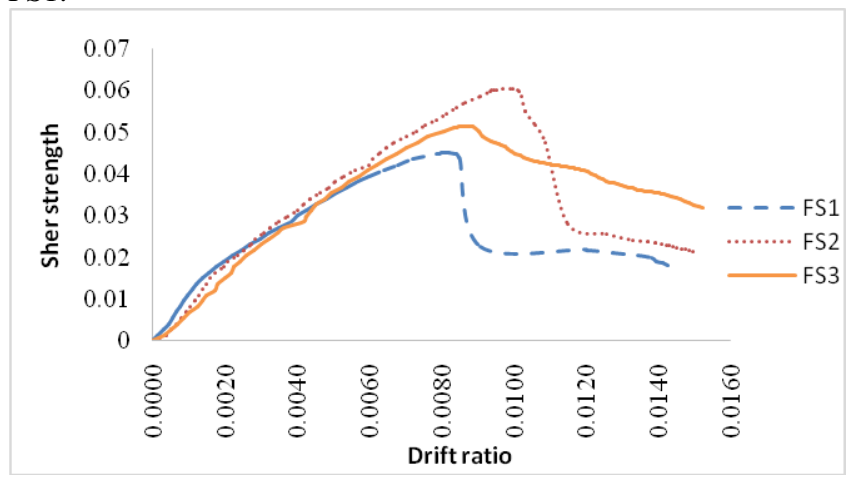

Figure 10: Normalized graph of flat slab specimens.

\section{Conclusions}

A brief introduction about flat slab is presented in this paper, together with the issue of punching shear failure. Various solutions to overcome the failure due to punching including different types of punching shear reinforcement were also mentioned.

In addition, three flat slabs were cast, where two specimens are equipped with punching shear reinforcement in the form of shear stirrups and structural shearbands and they are tested for punching. The objective of this experiment was to study and evaluate the behavior of flat slabs with and without punching shear reinforcement. The conclusions drawn from the experimental program are listed below.

1. The load carrying capacity of flat slab specimen with punching shear reinforcement is found to be greater than that of flat slab without punching shear reinforcement.

2. The failure of FS1 was brittle in nature, whereas the failure of FS2 and FS3 was ductile.

3. The shear strength of specimens with shear reinforcement is greater than that of specimens without punching shear reinforcement. It shows that FS2 and FS3 had higher ability to withstand the failure due to applied load than FS1. 
4. The stiffness degradation of FS1 is far greater than FS2 and FS3.

5. The stresses developed in FS2 and FS3 is higher than FS1 which implies that the load carrying capacity of the specimens with shear reinforcement is more than those without.

6. Placing shearband reinforcement has proved to be easier and time saving than placing shear stirrups, as shearbands is placed over the top mat of slab reinforcement.

\section{References}

[1] N. Subramanian, "Alternative punching shear reinforcement for RC flat slabs," Indian Concrete Journal, vol. 88, no. 1. pp. 33-44, 2014.

[2] Bureau of Indian Standard(BIS), "Plain and Reinforced Concrete Code of Practice," IS 456(4th rev.), no. July, p. New Delhi, India, 2000 .

[3] K. Pilakoutas and X. Li, "Alternative shear reinforcement for reinforced concrete flat slabs," J. Struct. Eng., vol. 129, no. 9, pp. 1164-1172, 2003

[4] IS 10262, "Recommended Guidelines for Concrete Mix Design," Indian Stand. Bur. Indian Stand., vol. 1982, 2009.

[5] K. N. Mate and P. S. Patil, "Study of Flat Slab," vol. 4, no. 6, pp. 1106-1110, 2015

[6] R. T. S. Mabrouk, A. Bakr, and H. Abdalla, "Effect of flexural and shear reinforcement on the punching behavior of reinforced concrete flat slabs," Alexandria Eng. Journal., vol. 56, no. 4, pp. 591-599, 2017.

[7] D. D. Ivan Duvnjak, Marko Bartolac, "Punching strength of flat slabs with and without shear reinforcement," ACI Struc. J., vol. 108, no. 2, pp. 197-205, 2011

[8] S. S. Patil and R. A. Sigi, "Flat Slab Construction in India," vol. 3, no. 10 , pp. 138-141, 2014

[9] J. J. Patel and N. Dubey, "Comparison of Analysis Methods of Flat Slab," vol. 2, no. 12, pp. 459-463, 2016.

[10] N. Subramanian, "Design of reinforced concrete structures", Oxford university press(2016). 